\title{
PENGUKURAN RESISTIVITAS LAPISAN TANAH DI KELURAHAN TUAH KARYA MENGGUNAKAN KONFIGURASI SCHLUMBERGER
}

\author{
Hafiza Mudral ${ }^{*}$, Usman Malik \\ Jurusan Fisika, Fakultas Matematika dan Ilmu Pengetahuan Alam, Universitas Riau, Kampus Bina Widya \\ J1. Prof. Muchtar Luthfi Pekanbaru, 28293, Indonesia \\ *e-mail: hafizamudral0802@gmail.com
}

\begin{abstract}
ABSTRAK
Geolistrik merupakan salah satu metode eksplorasi geofisika yang menggunakan sifat kelistrikan bumi untuk mempelajari keadaan bawah permukaan, metode geolistrik memiliki beberapa aturan yakni salah satunya aturan Schlumberger. Penelitian ini bertujuan untuk mengetahui susunan lapisan tanah, sehingga dapat diketahui penyebab air permukaan sulit meresap ke tanah berdasarkan nilai resistivitas di Perumahan HSB Indah Residence. Penelitian konfigurasi Schlumberger menggunakan bentangan 300 meter. Resistivitas litologi penyusun tanah di daerah penelitian dihasilkan dengan mengolah data geolistrik menggunakan software progress satu dimensi. Hasil penampang struktur lapisan batuan terdiri dari lima lapisan yaitu lapisan pertama merupakan lapisan lempung dengan nilai resistivitas 13,49 $\Omega$ m, lapisan kedua merupakan lapisan lanau dengan nilai resitivitas 42,88 $\Omega$ m, lapisan ketiga merupakan lapisan lempung yang dengan nilai resistivitasnya 1,87 $\Omega$ m, lapisan keempat merupakan lapisan batu pasir dengan nilai resistivitasnya 59,17 $\Omega \mathrm{m}$ dan lapisan kelima merupakan lapisan pasir kerikil dengan nilai resistivitasnya $443,40 \Omega \mathrm{m}$. Hal ini menunjukkan bahwa penyebab air permukaan selalu tergenang di sekitar perumahan adalah lapisan tanah didominasi oleh material lempung dan lanau dengan kedalaman lebih dari 25 meter.
\end{abstract}

Kata Kunci : Lapisan Tanah; Konfigurasi Schlumberger; Resistivitas.

\begin{abstract}
[Title: Soil Resistivity Measurement In The Tuah Karya Village By Schlumberger Configuration] Geoelectric is one of the geophysical exploration methods that uses the earth's electrical properties to study subsurface conditions, the geoelectric method has several rules, one of which is Schlumberger's rule. This study aims to determine the composition of the soil layer, so that it can be known that the cause of difficult surface water seeps into the ground based on resistivity values at the HSB Indah Residence. Schlumberger configuration research uses a 300 meter stretch. Resistivity of soil constituent lithology in the study area was generated by processing geoelectric data using one-dimensional progress software. The cross section of the rock structure consists of five layers, namely the first layer is a clay layer with a resistivity value of $13.49 \Omega \mathrm{m}$, the second layer is silt layer with a resistance value of $42.88 \Omega \mathrm{m}$, the third layer is a clay layer with a value of $1.87 \Omega \mathrm{m}$, the fourth layer is a layer of sandstone with a resistivity value of $59.17 \Omega \mathrm{m}$ and the fifth layer is a layer of gravel sand with a resistivity value of $443.40 \Omega \mathrm{m}$. This shows that the cause of surface water is always flooded around the housing area, the soil layer is dominated by clay and silt material with a depth of more than 25 meters.
\end{abstract}

Keywords: Soil Layer; Schlumberger Configuration: resistivity.

\section{PENDAHULUAN}

Air adalah sumberdaya yang terbaharui, bersifat dinamis mengikuti siklus hidrologi yang secara alamiah dapat berpindah-pindah serta mengalami perubahan bentuk dan sifat. Air tanah adalah air yang tersimpan pada lajur jenuh, yang kemudian bergerak sebagai aliran melalui batuan dan lapisan-lapisan tanah yang ada di bumi. Air tanah terdapat pada lapisan akuifer, yaitu lapisan pembawa air yang berada di bawah permukaan tanah. Lapisan ini terletak pada kedalaman tertentu, bahkan bisa mencapai kedalam hingga 100 meter. Lapisan ini tersusun oleh batuan yang kedap air (Kodoatie, 2012). Beberapa metode penyelidikan permukaan tanah yang dapat dilakukan diantaranya adalah metode geologi, gravitasi, magnit, seismik dan geolistrik. 
Salah satu syarat pemilihan rumah yang nyaman di suatu perumahan adalah bebas dari bencana alam banjir. Perumahan HSB Indah Residence yang terletak di Jalan Swakarya, Kelurahan Tuah Karya Kecamatan Tampan Pekanbaru, termasuk pada salah satu perumahan yang air selalu meluap di permukaan dan sulit untuk meresap ke tanah sampai di sekitar perumahan mengalami banjir. Penelitian ini dilakukan untuk mengukur resistivitas di perumahan tersebut, sehingga diketahui struktur lapisan bawah tanah dan diinterpretasi material penyusunnya. Secara umum, metode yang digunakandalam mengukur resistivitas lapisan tanah adalah metode geolistrik.

Metode geolistrik merupakan salah satu metode eksplorasi geofisika yang menggunakan sifat kelistrikan bumi untuk mempelajari keadaan bawah permukaan, seperti statigrafi, struktur litologi, distribusi sifat material dan sebagainya. Metode geolistrik dengan konfigurasi elektroda Schlumberger dilakukan dengan cara mengkondisikan jarak antara elektroda potensial dan jarak antara elektroda arus berubah secara bertahap (Sheriff, 2002).

Adapun tahapan yang dilakukan untuk memprediksi lapisan batuan pembawa air tanah yaitu, interpretasi nilai resistivitas masing-masing lapisan batuan untuk memperoleh kedalaman dan ketebalan lapisan tanah. Nilai resistivitas sebenarnya dapat dilakukan dengan cara pencocokan (matching) atau dengan metode inversi. Metode inversi yang digunakan pada penelitian ini adalah menggunakan program software progress (Purnama, 2013).

Penelitian ini akan menghasilkan model satu dimensi secara horizontal dari struktur litologi di Perumahan HSB Indah Residence.

\section{TINJAUAN PUSTAKA}

\section{TANAH}

Tanah adalah lapisan tipis kulit bumi dan terletak paling luar. Secara fisik, tanah merupakan benda alami heterogen yang terbentuk dari partikelpartikel mineral dan organik dari berbagai ukuran. Diantara partikel-partikel tersebut terdapat poripori yang berisi air dan udara, dan mempunyai sifat serta perilaku yang dinamik.Tekstur tanah merupakan salah satu sifat tanah yang dapat menentukan tata air dalam tanah, yaitu berupa kepatan infiltrasi, penetrasi dan kemampuan pengikat air oleh tanah. Tekstur tanah memilki beberapa kelompok, yaitu tanah bertekstur halus (liat), tanah bertekstur sedang dan tanah bertekstur kasar (Allan, 1982).
Air tanah adalah semua air yang terdapat pada lapisan mengandung air di bawah permukaan tanah, termasuk mata air yang muncul di permukaan tanah. Sumber air tanah berasal dari air yang ada di permukaan tanah kemudian meresap ke dalam tanah di daerah imbuhan (recharge area) dan mengalir menuju ke daerah lepasan (discharge area).

Air bawah tanah salah satu fase dalam siklus daur hidrologi, yang merupakan satu peristiwa yang terjadi secara berulang pada tahap yang dilalui air dari atmosfer ke bumi dan kembali lagi ke atmosfer. Penguapan dari darat, laut dan air kedalaman, pengembunan dalam pembentukan awan, pencurahan dan penguapan (Todd, 1980).

Aliran air tanah dalam perjalanannya melewati suatu lapisan akuifer yang di atasnya memiliki lapisan penutup yang bersifat kedap air, hal ini mengakibatkan perubahan tekanan antara air tanah yang berada di bawah lapisan penutup dan air tanah yang berada di atasnya. Perubahan tekanan ini yang didefenisikan sebagai air tanah tertekan (air tanah dalam) dan air tanah bebas (air tanah dangkal) (Ray, 1989).

\section{AKUIFER}

Akuifer adalah lapisan bawah tanah yang mengandung air dan mampu mengalirkan air.Contoh batuan pada lapisanakuifer adalah pasir, kerikil, batu pasir, batu gamping rekahan.Akuifer terdapat beberapa jenis akuifer, yaitu akuifer terkungkung (confined aquifer), akuifer setengah terkungkung (semi confined aquifer), akuifer setengah bebas (semi unconfined aquifer), dan akuifer bebas (unconfined aquifer) (Telfod, 1990).

\section{RESISTIVITAS}

Konsep dasar metode resistivitas adalah Hukum Ohm (Slamet, 1981).

$$
V=I R
$$

Tahanan jenis listrik suatu bahan (material) didefinisikan sebagai :

$$
=R \frac{A}{L}
$$

Ditinjau sebuah kawat dengan panjang $l$ terhubung potensial di setiap ujung-ujungnya sebesar $V_{l}(+)$ dan $V_{2}(-)$ sehingga memberikan beda potensial $\Delta V$ maka,

$$
=\frac{V}{I} \frac{A}{L}
$$


Metode resistivitas dengan konfigurasi Schlumberger dilakukan dengan cara mengkondisikan spasi antar elektroda potensial adalah tetap sedangkan spasi antar elektroda arus berubah secara bertahap. Pengukuran resistivitas pada arah vertikal atau vertical electrical sounding (VES) merupakan salah satu metode geolistrik resistivitas untuk menentukan perubahan resistivitas tanah terhadap kedalaman yang bertujuan untuk mempelajari variasi resistivitas batuan di bawah permukaan bumi secara vertikal [9].

Koreksi faktor geometris metode Sclumberger, sebagai berikut :

$$
K=-\frac{L^{2}}{2} \quad \frac{a^{2}}{2}
$$

dan tahanan jenis semu, sebagai berikut :

$$
{ }_{a}=-\frac{L^{2}}{2} \quad \frac{a^{2}}{2} R
$$

\section{METODEPENELITIAN}

Pengukuran resistivitas dilaksanakan di Perumahan HSB Indah Residence, Jalan Swakarya Kelurahan Tuah Karya, Tampan Pekanbaru pada bulan Februari 2019 dengan koordinat $0^{\circ} 2720.40 \quad 0^{\circ} 2718,54 \mathrm{~N}$ dan

\section{$101^{\circ} 2251,73 \quad 101^{\circ} 230,86 E$.}

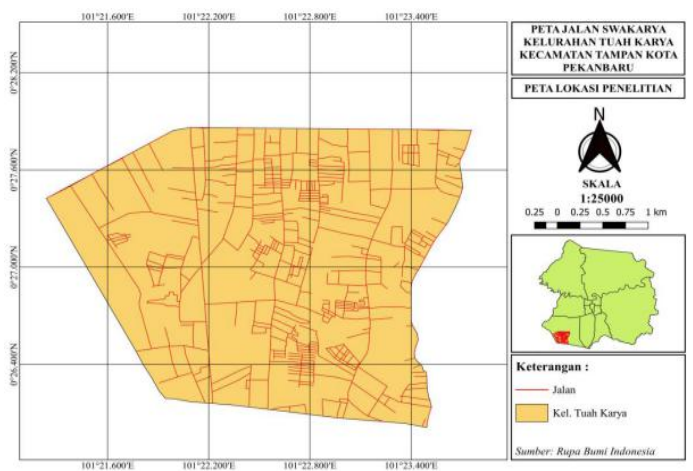

Gambar 1. Lokasi Penelitian

Pengukuran resistivitas lapisan tanah sepanjang lintasan 300 meter menggunakan metode geolistrik Schlumberger.

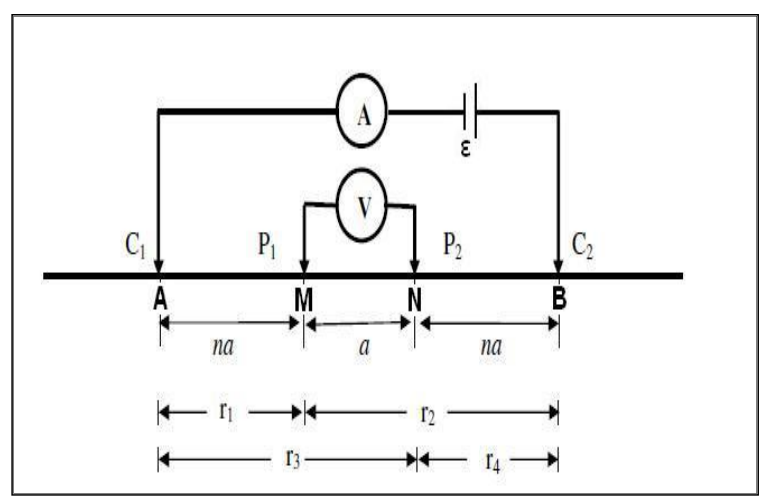

Gambar 2. Susunan elektroda Schlumberger.

Titik acuan dimulai dari titik tengah dari panjang lintasan. Kabel-kabel dihubungakan pada elektroda arus dan elektroda potensial serta dihubungkan pada alat resistivitimeter. Atur jarak eletroda, jarak elektroda MN adalah sebesar dua meter dan jarak elektroda AB adalah sebesar delapan meter. Hubungkan resistivitimeter pada accu, kemudian catat hasilnya dan lakukan pengukuran dengan memindahkan elektroda dengan jarak elektroda $A B$ sejauh empat meter serta jarak $\mathrm{MN}$ sejauh satu meter sampai dengan panjang lintasan yang diukur selesai. Hasil yang didapat akan diolah menggunakan program komputer software progress. Software Progress adalah program komputer yang secara otomatis akan menentukan data dalam bentuk satu dimensi (1-D).

\section{HASIL DAN PEMBAHASAN}

Nilai resistivitas batuan merupakan hasil yang diperoleh dari penelitian dan memiliki nilai yang berbeda-berdeba dan bergantung pada kondisi batuannya. Pengukuran geolistrik dilakukan di Perumahan HSB Indah Residence. Data yang diperoleh di titik pengukuran berupa nilai resistivitas, ketebalan dan kedalaman dari titik pengukuran secara horizontal (1D).

Hasil pengolahan data ditunjukkan pada Gambar 3, kemudian diinterpretasikan data yang menunjukkan lima lapisan tanah (Tabel 1) yaitu 13,49 $\Omega \mathrm{m}$ (lapisan lempung) dengan ketebalan 9 meter, 42,88 $\Omega \mathrm{m}$ (lapisan lanau) dengan ketebalan 11 meter, 1,87 $\Omega \mathrm{m}$ (lapisan lempung) dengan ketebalan 5 meter, 59,17 $\Omega \mathrm{m}$ (lapisan batu pasir) dengan ketebalan 23 meter dan 443,40 $\Omega$ m (lapisan pasir kerikil) pada ketebalan sampai tak hingga. Berdasarkan nilai resistivitas, lapisan pertama, kedua dan ketiga merupakan lapisan impermeable yaitu lapisan yang sulit menyerap air dan lapisan keempat merupakan lapisan pembawa air (akuifer) yaitu lapisan batu pasir. Sedangkan, lapisan kelima yaitu lapisan pasir kerikil diduga sedikit mengandung air. 


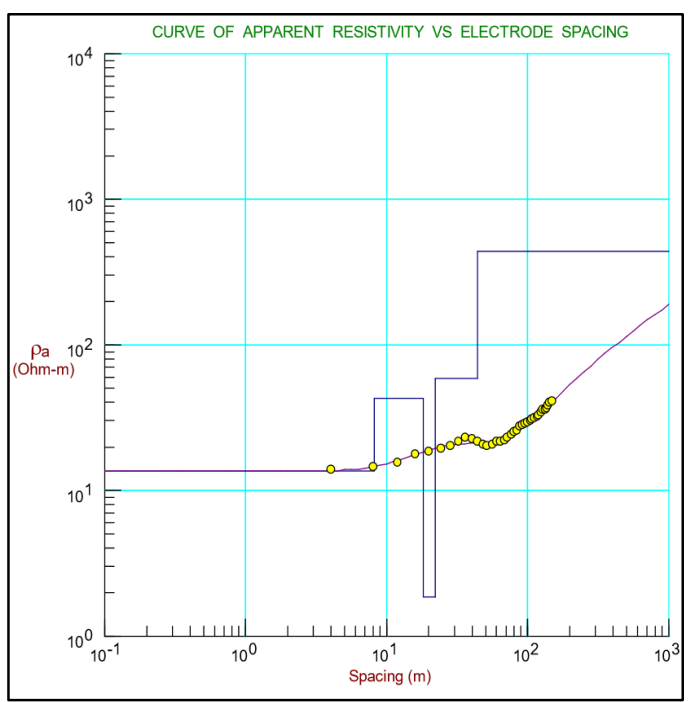

Gambar 3. Hasil pengolahan data.

Tabel 1. Hasil interpretasi lapisan tanah.

\begin{tabular}{ccc}
\hline $\begin{array}{c}\text { Kedalaman } \\
(\mathrm{m})\end{array}$ & $\begin{array}{c}\text { Resistivitas } \\
(\Omega \mathrm{m})\end{array}$ & Litologi \\
\hline $0,00-8,00$ & 13,49 & Lapisan Lempung \\
$8,00-18,00$ & 42,88 & Lapisan Lanau \\
$18,00-22,00$ & 1,87 & Lapisan Lempung \\
$22,00-44,00$ & 59,17 & Lapisan Batu Pasir \\
$44,00-\sim$ & 443,40 & Pasir Kerikil \\
\hline
\end{tabular}

\section{KESIMPULAN}

Berdasarkan hasil pengolahan data software progress terdapat lima lapisan tanah berserta nilai resistivitas nyata. Lapisan pertama merupakan lapisan lempung dengan nilai resistivitas 13,49 $\Omega \mathrm{m}$ pada kedalaman 0-8 meter, lapisan kedua merupakan lapisan lanau dengan nilai resitivitas 42,88 $\Omega \mathrm{m}$ pada kedalaman 8-18 meter dan lapisan ketiga memiliki pola yang sama dengan lapisan pertama yitu lapisan lempung dengan nilai resistivitas 1,87 $\Omega \mathrm{m}$ pada kedalaman 18-22 meter, lapisan keempat merupakan lapisan batupasir yang nilai resitivitasnya 59,17 $\Omega \mathrm{m}$ pada kedalaman 22-44 meter, diduga adalah lapisan pembawa air di bawah permukaan tanah (akuifer) dan lapisan kelima merupakan lapisan pasir kerikil yang nilai resistivitasnya $443,40 \Omega \mathrm{m}$ pada kedalaman 44 meter, merupakan lapisan bedrock (lapisan batu dasar). Penyebab air permukaan selalu meluap di perumahan adalah lapisan tanah yang didominasi oleh material lempung dan lanau dengan kedalaman 25 meter di bawah permukaan tanah. Lempung dan lanau yang terdapat pada lapisan pertama sampai dengan ketiga merupakan tanah yang sulit menyerap air.

\section{DAFTAR PUSTAKA}

Allan, L. Nicholas K., Koch. 1982. Physics Geology. New York : Cambridge University Press.

Kodoatie, Robert J. 2012. Tata Ruang Air Tanah. Yogyakarta: Andi.

Purnama, Setyawan. 2013. Analisis Karakteristik Akuifer Berdasarkan Pendugaan Geolistrik Di Pesisir Kabupaten Cilacap Jawa Tengah. Jurnal Geografi. Vol. 11 No. 22. Hal : 155-165.

Ray, L. K. J. R., M. A. Kohler dan J. L. H. Paulus. 1989. Hidrologi Untuk Insinyur. Jakarta: Erlangga.

Slamet dan Ruhiyat Husen. 1981. Geofisika Eksplorasi Terbatas. Bandung : LembagaFisika Nasional - Lembaga Ilmu PengetahuanIndonesia.

Sheriff, R. E. 2002. Encyclopedic Dictionary Of Applied Geophysics. $4^{\text {th }}$ edition. SEG Tulsa : Oklahoma.

Telford W. M. 1990. Applied Geophysic. New York : Cambridge University Press.

Todd, D.K. 1980. Groundwater Hydrology. New York : Wiley and Sons Inc. 